\title{
FACTORS AFFECTING ADMINISTRATIVE AND ORGANIZATIONAL SUCCESS IN THE TURKEY'S FORESTRY
}

\author{
KÖSE, M. ${ }^{1}$ - DAŞDEMIR, I. ${ }^{2 *}-$ YURDAKUL EROL, S. ${ }^{3}-$ YILDIRIM, H.-T. $^{3}$ \\ ${ }^{I}$ Çanakkale Onsekiz Mart University, Bayramiç Vocational School, Çanakkale, Turkey \\ (e-mail:muratkose@comu.edu.tr) \\ ${ }^{2}$ Bartın University, Faculty of Forestry, Bartın, Turkey \\ ${ }^{3}$ İstanbul University Cerrahpaşa, Faculty of Forestry, İstanbul, Turkey \\ (e-mail: secily@istanbul.edu.tr, htezcan@istanbul.edu.tr) \\ *Corresponding author \\ e-mail: isdasdemir@hotmail.com
}

(Received $6^{\text {th }}$ Mar 2019; accepted $3^{\text {rd }}$ May 2019)

\begin{abstract}
This study was dealt with aiming to examine the most important factors (education and selfdevelopment, administrative competence, success mentality, motivation and rewarding) affecting administrative and organizational success in the forest resource management of Turkey. For this purpose, four different questionnaires were applied to the total of 565 interviewees related to the forestry section of the Ministry of Forestry and Water Affairs and four different interest groups (employees, subject experts, related institutions and nongovernmental organizations representatives) in nine geographical regions of Turkey. To gather data about the subject and to reach the results, face to face interviews were conducted with interest groups, a questionnaire was applied. The layered-simple random sampling method was used as a sampling method. All obtained data were used as material. The research data were evaluated with descriptive statistics, it was inspected with the Kruskal-Wallis H-Test whether the thoughts of the interviewees related to the most important factors affecting administrative and organizational success differ according to the regions, and the departments, the position and the experience. The different groups were determined by the Duncan Test. Accordingly, most of the interviewees think that the undergraduate education, prevocational and in-service training are inadequate and that they need the most social and economic comprehensive information in the management of forest resources. Middle and upper level managers have the opportunity to further develop themselves, as the duration of experience increases, the administrative competence about forest resources management increases, but scientific studies and research results related to forestry are mostly not followed. The majority of the interviewees correctly identified administrative and organizational success in forestry, determined the most important factors affecting success as organizational and administrative factors and found that there was little or no relationship between success and reward. To increase the success in the forestry, the employees should participate in decisions and the success should be measured and evaluated objectively and numerically in the form of institutional success. According to the results, some suggestions were put forward for development of forest resources management.
\end{abstract}

Keywords: forest resource management, education, administrative competence, success mentality, motivation and rewarding, Turkey

\section{Introduction}

Sustainability and multiple utilization principles in forest resources management form the basis of contemporary forestry approach (Aktan, 2013; Lorincova et al., 2016; Albuquerque da Silva et al., 2016; Sanchez Badini et al., 2018). Many issues such as sustainable forest management, participatory management, conflict management, certification, carbon management and strategic management come to the fore in the field of forestry all over the world (Wibowo and Giessen, 2015; Kim et al., 2016). Human 
resources is the key factor to fulfill the innovations in those mentioned fields and provide sustainability in forestry and sustainability couldn't be ensured unless sufficient development is achieved in terms of human resources (Pinstrup-Andersen et al., 1998; Szaro et al., 2000). Considering the multifunctional services of forests in the planning and management processes are gradually becoming important in terms of conservation, development and expansion of the forest lands within the context of sustainable management (Baynes et al., 2015; Miteva et al., 2015). Parallel to this approach human resources, particularly the technical staff, has an important role in utilizing forest resources, actualizing new approaches in forestry and achieving the goals of forestry policy (Krott, 2005; Mendes, 2006). In other words, it is impossible to determine and implement effective policies, to solve numerous problems and to achieve sectoral progress without solving the problems of human resources in forestry (Hasanagas, 2014; Wibowo and Giessen, 2015).

Conserving the forest lands and providing the society with forest products sustainably are the duties, which are assigned through the constitution and the legislation, of the forestry organization in Turkey. Fulfillment of this duty as precisely as possible makes it obligatory for the organization to be dispersed and nature compatible (Toksoy et al., 2011). The country-wide problems such as complicated organizational structure, political oppression over the forestry organization and the employees, unequal distribution of human resources to central and provincial units, various unjust appointment and promotion issues are of the main factors that affect human resources (Özdönmez et al., 1998; Gümüş, 2014). Considering the issues listed above for Turkey, it can be clearly observed how essential it is to provide the employees, particularly the technical staff, with job satisfaction. In other words, human resources require to be managed well to ensure sustainable forest resources management. Within this context, it is seen that the concepts such as education, motivation, organizational and administrative success become prominent with regard to sustainable forest resources management (Torres-Rojo et al., 2016; Tumbach et al., 2018).

The characteristics of the forestry practices and the duties of the forestry organization require the staff that is to be employed in the field be specialized in terms of training and education (Kaplan, 1998; Hansman et al., 2016). The organizational structure which is established for the performance of forestry practices also diversifies the training and education of the personnel (Özdönmez et al., 1998). Meanwhile, the absence of a widespread and well-organized education system is a common obstacle against properly benefiting from educated staff for many countries. Although developing countries possess $50 \%$ of the whole world's forest lands, they employ only a small proportion of professional foresters and technicians (Schmithüsen, 1983; Elands et al., 2004; MacDicken et al., 2015). On the other hand, when forestry is analyzed in terms of human resources in developed countries, it is seen that training and development of the staff is among the mostly emphasized issues (Imamura, 1982; Hajjar and Oldekop, 2018). Therefore, the importance of well-trained and educated professional human resources for the sake of sustainable forest resources management can be clearly observed.

Monitoring the moral and physical needs of the employees, providing the work environment that meet their goals and expectations, ensuring the consistency among the organizational goals and staff goals in order to enhance motivation and improve labor productivity are considered as basic management processes not only for the motivation of the employees but also for the achievement of organizational goals (Gümüş and Beşir, 2012; Lyons et al., 2016). The most effective motivation tools are determined as 
satisfying wages, appreciation, job security, promotion and work satisfaction (Wiley, 1997; Burns and Giessen, 2016). In this regard, the motivation of the employees of the organization in parallel with the job satisfaction among them is crucially important when organizational success and the achievement of future goals are considered.

Forestry organization is an economic organization with public responsibilities, goals and duties to achieve (Daşdemir, 1998). Before determining the factors that affect success in this organization, it is necessary to identify what success means for it. In general, success for an organization is a multi-dimensional concept according to contemporary management approach and can be identified as the level of qualitative and quantitative achievement in scheduled activities, duties and goals with the interactive cooperation of all components of the system (Daşdemir, 1996; Akal, 2005). Despite it is possible to measure success in absolute and relative terms; it is possible to mention about different kinds of success such as economic success, technical success, biological and biophysical success, administrative and organizational success etc. Administrative and organizational success mostly related with organizational, environmental and human factors. The administrative dimension of success is a factor of production that actualizes the administration function. The core of this production factor is human, in other words, the administrators. Accordingly, administrators are responsible for the achievement of organizational goals by combining the efforts of the employees with the other resources within a process that consists of activities such as planning, decision making, organizing, leading, coordinating and supervising. Then, the characteristics that administrators should bear, emerge as the factors that form the most crucial dimension of organizational success. These factors affect the administrative success and hence are dependent on the environmental, organizational and administrative ones (Daşdemir, 1998).

Forestry in Turkey is based on public administration and public property. The institutions which are responsible for forest resources management in Turkey are the General Directorate of Forestry (GDF), the General Directorate of Nature Conservation and National Parks (GDNCNP) and the General Directorate of Combating Desertification and Erosion (GDCDE) under the Ministry of Forestry and Water Affairs (MFWA). The forestry organization, which is responsible for sustainable forest resources management, needs not only an ideal organizational structure but also employees with sufficiency and performance in order to achieve organizational goals and success. For this reason, it is important to identify the factors that affect the administrative and organizational success of the employees.

Therefore, this study aims to evaluate sustainable forest resources management efficiency, training, knowledge and supervision levels of the employees that work as administrators and technical staff in the forestry organization in Turkey. The study also aims to evaluate the administrative and organizational success mentality of the staff, their motivation level, motivation-success relation, measures to take in order to improve success and success measuring system. While evaluating the mentioned issues, the study considers the attitudes of four different interest groups which are the employees, experts, related institutions and nongovernmental organizations (NGO) representatives. The study has been conducted throughout the country among 565 participants including administrators and technical staff who work in forestry sector (GDF, GDNCNP and GDCDE) of the Ministry of Forestry and Water Affairs, and experts, related institutions and NGO representatives. The study has been carried out through interviews and questionnaires. The results are thought to contribute to sustainable forest resources 
management, human resources management, administrative and organizational success of forestry organization.

\section{Material and Method}

\section{Material}

The study has been carried out among the sample group that consists of the employees working in the forestry sector (GDF, GDNCNP and GDCDE) of the MFWA. The provinces (İstanbul, İzmir, Antalya, Adana, Bolu, Trabzon, Erzurum, Şanlıurfa and Ankara) with intense forestry activities have been included to represent the nine geographical regions of Turkey.

Participants belonging to four different interest groups, which are the employees, experts, related institutions and NGO representatives, from the cities listed above have been interviewed and questionnaires have been applied in order to evaluate the factors that affect administrative and organizational success in Turkish forestry sector. Four different interview and questionnaire forms had been prepared for each interest group. The questions in the forms are generally as follows: (1) The sufficiency of the education and the opportunity of self-development, (2) Administrative competence of the employees, (3) Success mentality and (4) Motivation. Similar and different questions were asked for each interest group in the questionnaire forms. The forms include both open-ended and closed-end questions. All kinds of qualitative and quantitative data obtained from research on four different interest groups and literature review are the main materials of the study.

\section{Data Collection Method}

The population of the study consists of the technical staff and administrators working in central and provincial units of forestry organization of the MFWA ( $\mathrm{N}=4704)$ (MFWA, 2016). The number of employees within the scope of this study was calculated using the following formula (Eq.l) related to the sample size in measurable groups (Orhunbilge, 2000; Daşdemir, 2016);

$$
\mathrm{n} \geq \frac{\mathrm{Z}^{2} \times \mathrm{N} \times \mathrm{p} \times \mathrm{q}}{\mathrm{N} \times \mathrm{D}^{2}+\mathrm{Z}^{2} \times \mathrm{p} \times \mathrm{q}}
$$

where $n$ is the size of the sample, $Z$ is reliability coefficient $(Z=1.96$ for $95 \%$ of confidence level), $N$ is the size of the population $(\mathrm{N}=4704), p$ is the existence possibility of the measured feature in the population, $q$ is absence possibility of the measured feature in the population $(\mathrm{p}=0.5 ; \mathrm{q}=0.5 \mathrm{a})$ and $\mathrm{D}$ is acceptable sampling error $(0.05)$.

According to this, $n$ was calculated as 355 and so the minimum number of the interviewees was determined. The minimum number of the participants to be interviewed for each region was calculated by multiplying the number of the employees in each region with the calculated $\mathrm{n} / \mathrm{N}$ coefficient which represents that each layer has been sampled in proportion to its percent. On the other hand, the number 355 was exceeded and 463 participants, who are technical staffs and administrators, were interviewed during the study (Table 1).

The interviewee and the questionnaire participants were selected randomly in each region. Thus, stratified-simple random sampling method was utilized in the study. 
As well as the staffs in the forestry organization, a survey research was carried out on 32 representatives of related institutions (municipal authorities, forestry faculties, provincial directorate of agriculture etc.), $37 \mathrm{NGO}$ representatives (the Chamber of Forest Engineers, the Foresters' Association of Turkey, the Foundation for the Promotion and Protection of the Environment and Cultural Heritage, forestry cooperatives, Village Headmen Association, Forestry Union etc.) and 33 experts who have scientific studies on forest resources management or who have been working in forestry organization as administrator for many years and have knowledge on administration of forestry organization and restructuring. Since the actual numbers of other interest groups in each region were small, the survey was conducted in full field (on all their numbers) in each region. Therefore, the sample sizes of other interest groups are equal to their actual numbers. Thus, a total of 565 participants from the four different interest groups were interviewed (Table 1).

Table 1. Numbers of the interviewed participants for all interest groups

\begin{tabular}{|c|c|c|c|c|c|c|c|c|c|c|c|c|c|c|c|c|}
\hline \multirow{4}{*}{ Regions } & \multicolumn{12}{|c|}{ Staffs in Forestry Organization } & \multirow{4}{*}{ Institutions } & \multirow{4}{*}{$\mathrm{NGO}$} & \multirow{4}{*}{ Experts } & \multirow{4}{*}{$\begin{array}{c}\text { General } \\
\text { Total }\end{array}$} \\
\hline & \multirow{2}{*}{\multicolumn{2}{|c|}{ GDF }} & \multirow{2}{*}{\multicolumn{2}{|c|}{ GDNCNP }} & \multirow{2}{*}{\multicolumn{2}{|c|}{ GDCDE }} & \multirow{2}{*}{\multicolumn{2}{|c|}{$\begin{array}{c}\text { Center of the } \\
\text { MFWA }\end{array}$}} & \multirow{2}{*}{\multicolumn{4}{|c|}{$\begin{array}{l}\text { General } \\
\text { Sample }\end{array}$}} & & & & \\
\hline & & & & & & & & & & & & & & & & \\
\hline & Staff & ample & Staff & Sample & Staff & Sampl & Staff & Sample & Staff & $\begin{array}{l}\text { Technicic } \\
\text { staffs }\end{array}$ & $\begin{array}{l}\text { 1Adminis } \\
\text { trators }\end{array}$ & Total & & & & \\
\hline $\begin{array}{l}\text { Marmara } \\
\text { (İstanbul) }\end{array}$ & 721 & 62 & 73 & & & & & & 794 & 57 & 14 & 71 & 7 & 10 & 10 & 98 \\
\hline $\begin{array}{l}\text { Aegean } \\
\text { (İzmir) }\end{array}$ & 693 & 59 & 57 & 5 & & & & & 750 & 38 & 26 & 64 & 3 & 4 & 3 & 74 \\
\hline $\begin{array}{c}\text { Western } \\
\text { Mediterranean }\end{array}$ & 335 & 27 & 30 & 3 & & & & & 365 & 15 & 15 & 30 & 4 & & 4 & 43 \\
\hline $\begin{array}{c}\text { (Antalya) } \\
\text { Eastern }\end{array}$ & & & & & & & & & & & & & & & & \\
\hline $\begin{array}{c}\text { Mediterranean } \\
\text { (Adana) } \\
\text { Western }\end{array}$ & 459 & 49 & 30 & 15 & & & & & 489 & 48 & 16 & 64 & 4 & 4 & 3 & 75 \\
\hline $\begin{array}{c}\text { Black Sea } \\
\text { (Bolu) }\end{array}$ & 680 & 68 & 34 & 4 & & & & & 714 & 32 & 40 & 72 & 2 & 2 & 2 & 78 \\
\hline $\begin{array}{l}\text { Eastern Black } \\
\text { Sea (Trabzon) }\end{array}$ & 364 & 30 & 20 & 4 & & & & & 384 & 15 & 19 & 34 & 2 & 2 & 1 & 39 \\
\hline $\begin{array}{c}\text { Central } \\
\text { Anatolia } \\
\text { (Ankara) }\end{array}$ & 692 & 65 & 79 & 6 & 48 & 5 & 54 & 4 & 873 & 47 & 33 & 80 & 6 & 10 & 10 & 106 \\
\hline $\begin{array}{c}\text { Eastern } \\
\text { Anatolia } \\
\text { (Erzurum) }\end{array}$ & 187 & 20 & 21 & 3 & & & & & 208 & 8 & 15 & 23 & 2 & & & 25 \\
\hline $\begin{array}{c}\text { Southeastern } \\
\text { Anatolia } \\
\text { (Sanliurfa) }\end{array}$ & 89 & 18 & 38 & 7 & & & & & 127 & 13 & 12 & 25 & 2 & & & 27 \\
\hline TOTAL & 4220 & 398 & 382 & 56 & 48 & 5 & 54 & 4 & 4704 & 273 & 190 & 463 & 32 & 37 & 33 & 565 \\
\hline
\end{tabular}

The interviews were conducted in 2016. A pretesting was applied for the questionnaire. In the pretesting process, the attitudes of the participants about the questionnaire, the convenience of the questionnaire forms, the clarity of the questions and missing parts were determined, questionnaire form was rearranged. Then the participants were informed about the importance of the subject and the questionnaires were conducted through face to face meetings.

\section{Data Evaluation Method}

The data which are mostly qualitative and obtained from four different interest groups' questionnaire survey have been identified and digitized as variables in Table 2. 
The data was evaluated through descriptive statistics, the Kruskal-Wallis (K-W) $\mathrm{H}$ Test and the Duncan's Test and the results were shown in tables. The software Excel2010 and SPSS (22.0 version) were utilized to evaluate the data.

\section{Results}

\section{General Results on Participants and Evaluations}

A total of 565 people from four interest groups located in 9 geographical regions in Turkey were interviewed and questionnaires were conducted during this study. 463 of them work as manager and technical staff in the forestry organization. 59\% of the participants of the questionnaire are engineers, $11 \%$ are forest chiefs, $2 \%$ are deputy director of forest enterprises, $2 \%$ are managers of forest enterprises, and $24 \%$ are branch managers, deputy director or directors of regional directorates of forestry. Also, 52\% of the experts, number of which is 33, work under the MFWA, $42 \%$ are academicians from faculties of forestry and $6 \%$ are retired forest engineers. $28 \%$ of the 32 participants from related organization representatives are the employees of municipalities or various ministries, $53 \%$ are of forestry faculties, $19 \%$ are of other institutions related to forestry such as General Directorate of State Hydraulic Works (DSI) and General Directorate of Highways (TCK) etc. 34\% of these mentioned participants are technical staff, $13 \%$ are administrators and 53\% are academicians. On the other hand, $51 \%$ of the 37 participants, who are $N G O$ representatives, are either the members of the Chamber of Forest Engineers or the Foresters' Association, 8\% are the members of unions and $41 \%$ are the members of foundations etc. related to forestry. $68 \%$ of them are members, $32 \%$ are either managers or deputy managers.

The educational status, the administrative task duration and experience for the 463 participants who work as administrators and technical staff in the forestry sector across Turkey are indicated in Table 3.

Considering the Table 3, it can be understood that most of the questionnaire participants $(65 \%)$ have been working in their current administrative positions between 0-5 years. The rate of those who have been working in the same administrative position more than 11 years is $13 \%$. In other words, $87 \%$ of the staff working as administrators have worked in their position maximum for 10 years. Whereas $51 \%$ of the survey participants have a 20 -year job experience, $49 \%$ of the participants have an experience of 21 years or more. $73 \%$ of the participants have a bachelor's degree in forest engineering. Only $24 \%$ of them have either master or Ph.D. degree while $3 \%$ are graduates of some other faculties. This is an important progress in training qualified administrators and technical staff. Approximately $70 \%$ of the participants who were consulted as experts are either graduates of two different faculties or have graduate degree (master or Ph.D.).

\section{Sufficiency of Education and Opportunity of Self-Improvement}

In this part of the study, the employees in the forestry sector and the experts on organizational structure and administration were asked their attitudes about the sufficiency of the education received in forestry faculties on forest resources management, the sufficiency of the prevocational training, in-service training and human resources development activities provided by the forestry organization. 
Table 2. Identification of the variables

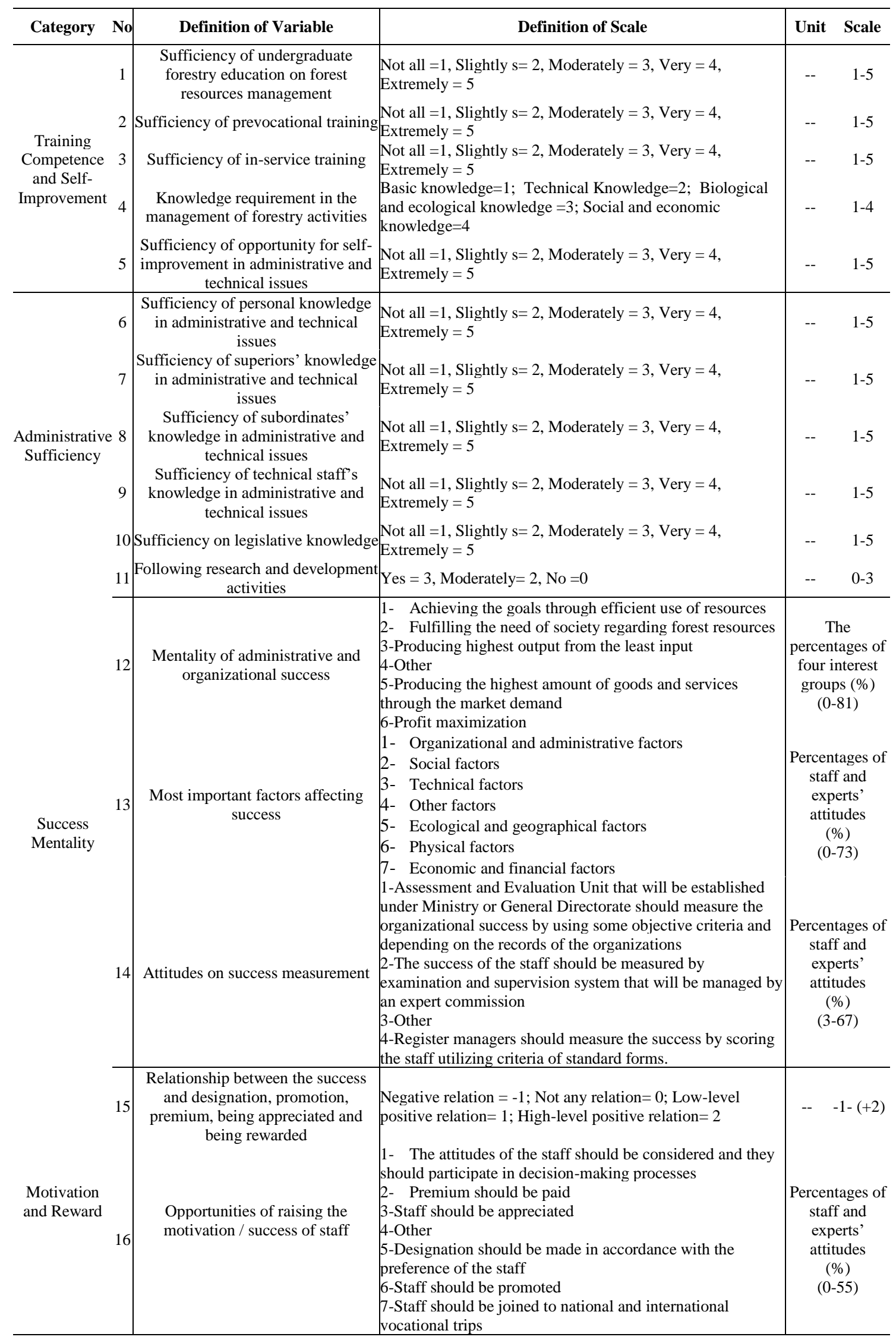


Table 3. Educational status, administrative task duration and experience of the participant staff

\begin{tabular}{|c|c|c|c|c|}
\hline \multirow{2}{*}{ Features } & \multirow{2}{*}{ Category } & \multirow{2}{*}{ Years } & \multicolumn{2}{|c|}{ Staff } \\
\hline & & & Frequency $(\mathbf{N})$ & Percentage (\%) \\
\hline \multirow{4}{*}{ Administrative Task Duration } & 1 & Less than 5 & 301 & 65 \\
\hline & 2 & $6-10$ & 100 & 22 \\
\hline & 3 & More than 11 & 62 & 13 \\
\hline & Total & & 463 & 100 \\
\hline \multirow{5}{*}{$\begin{array}{c}\text { Vocational Experience } \\
\text { (Career Duration) }\end{array}$} & 1. Low & Less than 10 & 121 & 26 \\
\hline & 2. Medium & $11-20$ & 117 & 25 \\
\hline & 3. High & $21-30$ & 185 & 40 \\
\hline & 4. Very High & More than 31 & 40 & 9 \\
\hline & Total & & 463 & 100 \\
\hline \multirow{4}{*}{ Education } & \multirow{4}{*}{\multicolumn{2}{|c|}{$\begin{array}{l}\text { Undergraduate } \\
\text { Graduate } \\
\text { Get degree from two Undergraduate } \\
\text { Programs } \\
\text { Total }\end{array}$}} & 339 & 73 \\
\hline & & & 111 & 24 \\
\hline & & & 13 & 3 \\
\hline & & & 463 & 100 \\
\hline
\end{tabular}

Besides, those working as administrators (on planning, organization, operation, and supervision) and technical staff were also asked what kind of knowledge background they require mostly and their attitudes on the opportunity of self-improvement. The attitudes of the participants were evaluated and the results were indicated in Table 4. The question, whether the attitudes of the employees differ depending on the regions, departments, position and job experience or not was tested through statistical analyses as well (Table 5).

Sixty-four percent of the participants who work for forestry organization and $73 \%$ of the experts define the sufficiency of the education received in forestry faculties on forest resources management as "moderately sufficient" (Table 4). As it is indicated in Table 5, the region, department and position have no significant effect on their attitude. However, as for job experience, $95 \%$ of reliability level makes a significant difference. It has been observed that less experienced employees (0-10 years of experience) generally define the sufficiency of the education received in forestry faculties on forest resources management as "slightly sufficient" and "moderately sufficient" whereas those with medium, high and quite high experience ( $\geq 11$ years) mostly define as "reasonably sufficient".

Forty-six percent of the employees find the prevocational training provided by the organization "moderately sufficient" (Table 4). At this point, the attitudes of the employees differ depending on the region with a reliability level of $99 \%$ whereas their attitudes have differences in terms of the position, department and experience with a reliability level of 95\%. While those who work in İstanbul, Şanliurfa, Adana, Antalya and İzmir generally find prevocational training "slightly sufficient", the staff work in Ankara, Bolu, Trabzon and Erzurum mostly find "moderately sufficient". When the departments are considered, those working at the General Directorate of Forestry (GDF) and the General Directorate of Nature Conservation and National Parks (GDNCNP) define training as "slightly sufficient" and "moderately sufficient". On the other hand, the employees working at the General Directorate of Combating Desertification and Erosion (GDCDE) find the mentioned training "moderately sufficient" and "very sufficient". Engineers also find the prevocational training provided by the organization "slightly sufficient" and "moderately sufficient" whereas operation chiefs, assistant 
operation managers, operation managers, branch managers, district managers and their assistants mostly find it "moderately sufficient". When job experience is considered, less experienced staff and those with medium experience (0-20 years) define their attitude as "hardly sufficient" and "moderately sufficient" whereas those with high and quite high experience ( $\geq 21$ years) generally define it as "moderately sufficient" (Table 5).

Table 4. Participants' attitudes on sufficiency of the education and opportunity of selfimprovement

\begin{tabular}{|c|c|c|c|}
\hline \multirow{2}{*}{ Attitudes } & \multirow{2}{*}{ Scale } & \multicolumn{2}{|c|}{ Percentages of attitudes (\%) } \\
\hline & & Staff & Experts \\
\hline \multirow{5}{*}{$\begin{array}{l}\text { 1. Sufficiency of } \\
\text { undergraduate education } \\
\text { on forest resources } \\
\text { management }\end{array}$} & a) Not all & 6 & 0 \\
\hline & b) Slightly & 20 & 9 \\
\hline & c) Moderately & 64 & 73 \\
\hline & d) Very & 8 & 15 \\
\hline & e) Extremely & 2 & 3 \\
\hline \multirow{5}{*}{$\begin{array}{l}\text { 2. Sufficiency of } \\
\text { prevocational training }\end{array}$} & a) Not all & 8 & - \\
\hline & b) Slightly & 38 & - \\
\hline & c) Moderately & 46 & - \\
\hline & d) Very & 7 & - \\
\hline & e) Extremely & 1 & - \\
\hline \multirow{5}{*}{$\begin{array}{l}\text { 3. Sufficiency of in- } \\
\text { service training }\end{array}$} & a) Not all & 4 & - \\
\hline & b) Slightly & 22 & - \\
\hline & c) Moderately & 60 & - \\
\hline & d) Very & 13 & - \\
\hline & e) Extremely & 1 & - \\
\hline \multirow{4}{*}{$\begin{array}{l}\text { 4. Knowledge } \\
\text { requirement in the } \\
\text { management of forestry } \\
\text { activities }\end{array}$} & $\begin{array}{c}\text { a) Basic knowledge (biology, physics, chemistry, } \\
\text { mathematics, statistics etc.) }\end{array}$ & 2 & 0 \\
\hline & $\begin{array}{l}\text { b) Technical knowledge (construction, } \\
\text { transportation, cadastre, watershed management etc.) }\end{array}$ & 18 & 0 \\
\hline & $\begin{array}{l}\text { c) Biological and ecological knowledge (ecology, } \\
\text { entomology, silviculture, afforestation etc.) }\end{array}$ & 30 & 18 \\
\hline & $\begin{array}{l}\text { d) Social and economic knowledge (economy, } \\
\text { business administration, production-marketing, } \\
\text { finance, planning, law, public relations etc.) }\end{array}$ & 50 & 82 \\
\hline \multirow{5}{*}{$\begin{array}{l}\text { 5. Opportunity for self- } \\
\text { improvement in } \\
\text { administrative and } \\
\text { technical issues }\end{array}$} & a) Not all & 3 & 0 \\
\hline & b) Slightly & 19 & 9 \\
\hline & c) Moderately & 57 & 70 \\
\hline & d) Very & 19 & 18 \\
\hline & e) Extremely & 2 & 3 \\
\hline
\end{tabular}

On the other hand, when the sufficiency of the in-service training is considered, $92 \%$ of the employees $(60+22+4)$ find it "moderately sufficient", "slightly sufficient" and "not sufficient" (Table 4). The attitudes of the employees regarding this matter differ depending on the position with a reliability level of $99 \%$ and on the region, department and experience with a reliability level of 95\%. Those working in İstanbul, Adana, Antalya, İzmir, Ankara, Bolu, Trabzon and Erzurum define the sufficiency of the inservice training and human resources development activities as "moderately sufficient" whereas those who work in Şanlıurfa mostly define it as "slightly sufficient". When the department is considered, employees at the GDF state "slightly sufficient" and "moderately sufficient" while the employees at the GDNCNP and the GDCDE generally state "moderately sufficient" and "very sufficient". Those working as engineers, forest chiefs and managers of forest enterprises generally state their attitudes 
as "slightly sufficient" and "moderately sufficient". However, deputy managers of forest enterprises, branch managers, directors and deputy directors of regional forest directorates define their attitude as "moderately sufficient" and "very sufficient". Similarly, employees with less, medium and high experience (0 -30 years) find related activities of the organization "slightly sufficient" and "moderately sufficient". Those with quite high experience ( $\geq 31$ years), on the other hand, generally find the activities "moderately sufficient" and "very sufficient" (Table 5).

Table 5. Difference among the attitudes of employees about sufficiency of education and opportunity of self-improvement depending on the region, department, position and experience

\begin{tabular}{|c|c|c|c|c|c|c|c|}
\hline \multirow{3}{*}{ Attitudes } & \multicolumn{3}{|c|}{$\begin{array}{l}\text { Kruskal-Wallis H-Test } \\
\text { Results }\end{array}$} & \multirow{2}{*}{\multicolumn{4}{|c|}{$\begin{array}{c}\text { Identify differences by Duncan Test } \\
\text { (Groups and in-group components are ranked as to their } \\
\text { significance level ) }\end{array}$}} \\
\hline & \multirow{2}{*}{ Criteria } & \multirow{2}{*}{$\begin{array}{l}\text { Khi- } \\
\text { square } \\
\text { value }\end{array}$} & \multirow{2}{*}{ SD } & & & & \\
\hline & & & & No & Component of the groups & $\overline{\mathrm{x}}$ & $\mathbf{N}$ \\
\hline \multirow{3}{*}{$\begin{array}{l}\text { 1. Sufficiency of } \\
\text { undergraduate education on } \\
\text { forest resources management }\end{array}$} & \multicolumn{5}{|c|}{ There is no significant difference with respect to region, department and position } & -- & -- \\
\hline & & & & 1 & Staff with low experience $(0-10$ years $)$ & 2.63 & 121 \\
\hline & Experience & $10.30^{*}$ & 3 & 2 & $\begin{array}{c}\text { Staff with medium, high and very high } \\
\text { experience }(\geq 11 \text { years })\end{array}$ & 2.86 & 342 \\
\hline \multirow{8}{*}{$\begin{array}{l}\text { 2. Sufficiency of } \\
\text { prevocational training }\end{array}$} & \multirow{2}{*}{ Region } & \multirow{2}{*}{$29.55^{* *}$} & \multirow{2}{*}{8} & 1 & İstanbul, Şanlıurfa, Adana, Antalya, İzmir & 2.38 & 254 \\
\hline & & & & 2 & Ankara, Bolu, Trabzon, Erzurum & 2.74 & 209 \\
\hline & \multirow{2}{*}{ Department } & \multirow{2}{*}{$7.94 *$} & \multirow{2}{*}{2} & 1 & GDF, GDNCNP & 2.58 & 458 \\
\hline & & & & 2 & GDCDE & 3.40 & 5 \\
\hline & & & & 1 & Engineer & 2.43 & 273 \\
\hline & Position & $14.69 *$ & 5 & 2 & $\begin{array}{l}\text { Forest chief, deputy manager of forest } \\
\text { enterprise, manager of forest enterprise, } \\
\text { branch manager, deputy manager and } \\
\text { manager of regional directorate }\end{array}$ & 2.72 & 190 \\
\hline & \multirow{2}{*}{ Experience } & \multirow{2}{*}{$9.72 *$} & \multirow{2}{*}{3} & 1 & $\begin{array}{l}\text { Staff with low and medium level experience } \\
\qquad(0-20 \text { years })\end{array}$ & 2.43 & 238 \\
\hline & & & & 2 & $\begin{array}{c}\text { Staff with high and very high experience } \\
(\geq 21 \text { years })\end{array}$ & 2.67 & 225 \\
\hline \multirow{8}{*}{$\begin{array}{l}\text { 3. Sufficiency of in-service } \\
\text { training }\end{array}$} & \multirow[b]{2}{*}{ Region } & \multirow[b]{2}{*}{$18.49 *$} & \multirow[b]{2}{*}{8} & 1 & Şanlıurfa & 2.44 & 25 \\
\hline & & & & 2 & $\begin{array}{l}\text { İstanbul, Adana, Antalya, İzmir } \\
\text { Ankara, Bolu, Trabzon, Erzurum }\end{array}$ & 2.89 & 438 \\
\hline & \multirow{2}{*}{ Department } & \multirow{2}{*}{$8.46^{*}$} & & 1 & GDF & 2.81 & 405 \\
\hline & & & & 2 & GDNCNP, GDCDE & 3.23 & 58 \\
\hline & \multirow[b]{2}{*}{ Position } & \multirow[b]{2}{*}{$18.87 * *$} & \multirow[b]{2}{*}{5} & 1 & $\begin{array}{c}\text { Engineer, Forest Chief, Manager of Forest } \\
\text { Enterprise }\end{array}$ & 2.88 & 332 \\
\hline & & & & 2 & $\begin{array}{l}\text { Deputy manager of forest enterprise, Branch } \\
\text { manager, Deputy manager and manages of }\end{array}$ & 3.11 & 131 \\
\hline & \multirow[t]{2}{*}{ Experience } & \multirow[t]{2}{*}{$8.65^{*}$} & \multirow[t]{2}{*}{3} & 1 & $\begin{array}{c}\text { regional directorate } \\
\text { Staff with low, medium, high experience }(0 \\
-30 \text { years })\end{array}$ & 2.81 & 423 \\
\hline & & & & 2 & Staff with very high experience ( $\geq 31$ years) & 3.05 & 40 \\
\hline $\begin{array}{l}\text { 4. Knowledge requirement in } \\
\text { the management of forestry } \\
\text { activities }\end{array}$ & There is no & significant & differ & $\begin{array}{r}\text { ence } \\
\text { and }\end{array}$ & $\begin{array}{l}\text { with respect to region, department, position } \\
\text { experience. }\end{array}$ & -- & -- \\
\hline & There is $\mathrm{n}$ & significan & differ & rence & with respect to department and experience. & -- & -- \\
\hline 5. Opportunity for self- & & & 8 & & İstanbul, Ankara, Şanlıurfa, Adana, İzmir & 2.86 & 304 \\
\hline improvement in & Kegion & & 8 & 2 & Bolu, Trabzon, Erzurum, Antalya & 3.17 & 159 \\
\hline $\begin{array}{l}\text { administrative and technical } \\
\text { issues }\end{array}$ & & & & 1 & Engineer, forest chief, branch manager & 3.04 & 436 \\
\hline & Position & $23.59 * *$ & 5 & 2 & $\begin{array}{l}\text { Manager and deputy manager of forest } \\
\text { enterprise and regional directorate }\end{array}$ & 3.40 & 27 \\
\hline
\end{tabular}

$*$ is significant at 0.05 confidence level; $* *$ is significant at 0.01 confidence level 
The complexity of tasks and responsibilities of national forestry organization and the overload job definition of forest engineers who work as land managers makes the importance of the education and training critical for Turkish forestry. The findings showed that both the undergraduate education and vocational education should be developed especially in the context of social and economic aspect. Also the training program's sufficiency is considered lower by GDF's staff than the others. The main reason of this result depends on the diversity of work, work load, task and responsibilities and also the size of organizational structure of GDF. Thus the priority should be given to this institute. This could affect both the personal and organizational performance.

Fifty percent of the employees working in forestry sector and $82 \%$ of the experts state that they mostly require social and economic (economics, management, production-marketing, accounting, planning, law and public relations etc.) knowledge background when they are asked "What kind of knowledge background do you require mostly with your position in the management of forestry activities (planning, organization, operation, and supervision)?" (Table 4). The difference of region, department, position and experience do not significantly affect the employees' attitude related to that aspect (Table 5).

Fifty-seven percent of the employees and $70 \%$ of the experts answer the question "Do you find the opportunity for self-improvement in your profession and technical issues?" as "moderately sufficient" (Table 4). The difference in department and experience do not significantly affect the employees' attitude related to the subject. However, it has been observed that the attitude of the employees differ depending on the region and position with a reliability level of $99 \%$. According to the scores of Duncan's test which was applied in order to find the difference among the groups, it has been found out that employees in İstanbul, Ankara, Şanlıurfa, Adana and İzmir generally state that self-development opportunity is "slightly" and "moderately sufficient". However, those working in Bolu, Trabzon, Erzurum and Antalya answer the same question as "moderately sufficient" and "very sufficient". On the other hand, engineers, forest chiefs and branch managers state this aspect as "moderately sufficient" whereas managers and deputy managers of forest enterprises and regional forest directorates state it as "moderately sufficient" (Table 5).

Self-improvement is also another important factor that affects the organizational success. It was found out that the self-improvement opportunities were commented in different levels by the regions. Especially the participants of the regions with higher development level such as Istanbul and Ankara expressed that they have lower level of related opportunities. The evaluation of this result in human resources management policies could support the regional level activities. The other interesting finding showed that the level of considering the sufficiency of self-improvement opportunities increase by the position. The reason of this result could be the differences between the duty places and conditions of the staff at different organizational levels. In this context, the staff with lower position level should be supported as a general policy.

\section{Results Related to Administrative Competence}

In this part of the study, the employees that work as administrator and technical in the forestry organization were asked to consider the sufficiency of themselves, their subordinates, superiors and technical staff about forest resources management, legislative knowledge and also their attitudes about following the research and 
development activities and outputs. Related results were indicated in Table 6. The question whether the attitudes of the employees relating the issue differ depending on the regions, departments, position and experience were tested through statistical analyses as well and the results were indicated in Table 7.

Table 6. Employees' attitudes on their administrative competence

\begin{tabular}{|c|c|c|}
\hline Attitudes & Scale & $\begin{array}{c}\text { Percentages of attitudes } \\
(\%) \\
\text { Staff } \\
\end{array}$ \\
\hline $\begin{array}{l}\text { 1. Sufficiency of personal } \\
\text { knowledge in administrative } \\
\text { and technical issues }\end{array}$ & $\begin{array}{l}\text { a) Not all } \\
\text { b) Slightly } \\
\text { c) Moderately } \\
\text { d) Very } \\
\text { e) Extremely }\end{array}$ & $\begin{array}{c}1 \\
8 \\
60 \\
28 \\
3\end{array}$ \\
\hline $\begin{array}{l}\text { 2. Sufficiency of superiors' } \\
\text { knowledge in administrative } \\
\text { and technical issues }\end{array}$ & $\begin{array}{l}\text { a) Not all } \\
\text { b) Slightly } \\
\text { c) Moderately } \\
\text { d) Very } \\
\text { e) Extremely }\end{array}$ & $\begin{array}{c}3 \\
17 \\
60 \\
18 \\
2 \\
\end{array}$ \\
\hline $\begin{array}{l}\text { 3. Sufficiency of subordinates' } \\
\text { knowledge in administrative } \\
\text { and technical issues }\end{array}$ & $\begin{array}{l}\text { a) Not all } \\
\text { b) Slightly } \\
\text { c) Moderately } \\
\text { d) Very } \\
\text { e) Extremely }\end{array}$ & $\begin{array}{c}3 \\
29 \\
60 \\
7 \\
1 \\
\end{array}$ \\
\hline $\begin{array}{l}\text { 4. Sufficiency of technical } \\
\text { staff's knowledge in } \\
\text { administrative and technical } \\
\text { issues }\end{array}$ & $\begin{array}{l}\text { a) Not all } \\
\text { b) Slightly } \\
\text { c) Moderately } \\
\text { d) Very } \\
\text { e) Extremely }\end{array}$ & $\begin{array}{c}1 \\
18 \\
68 \\
12 \\
1\end{array}$ \\
\hline $\begin{array}{l}\text { 5. Sufficiency on legislative } \\
\text { knowledge }\end{array}$ & $\begin{array}{l}\text { a) Not all } \\
\text { b) Slightly } \\
\text { c) Moderately } \\
\text { d) Very } \\
\text { e) Extremely }\end{array}$ & $\begin{array}{c}0 \\
10 \\
52 \\
34 \\
4 \\
\end{array}$ \\
\hline $\begin{array}{l}\text { 6. Following research and } \\
\text { development activities }\end{array}$ & $\begin{array}{ll} & \text { a) Yes } \\
& \text { b) No } \\
\text { c) } & \text { Moderately }\end{array}$ & $\begin{array}{l}12 \\
26 \\
62\end{array}$ \\
\hline $\begin{array}{l}\text { 7. Reason of not following } \\
\text { research and development } \\
\text { activities sufficiently }\end{array}$ & $\begin{array}{l}\text { a) I don't care } \\
\text { b) I care, however I don't have enough time } \\
\text { c) I'm not of interest } \\
\text { d) The research results aren't applied } \\
\text { e) I don't believe in researches and find them } \\
\text { insufficient } \\
\text { f) Other }\end{array}$ & $\begin{array}{c}1 \\
42 \\
8 \\
23 \\
8 \\
18 \\
\end{array}$ \\
\hline
\end{tabular}

As it can be concluded from Table 6, 60\% of the employees working in forestry organization find themselves "moderately sufficient" in forest resources management. The difference of department has no significant effect on the employees' attitudes related to the subject. However, when region and experience are considered, significant effect on the attitude can be seen with a reliability level of $99 \%$ and this rate is $95 \%$ when position is considered. Those who work in İstanbul, Ankara, Erzurum and Şanlıurfa find themselves "moderately sufficient" in forest resources management, whereas those working in Bolu, Trabzon, Adana, Antalya and İzmir state their competence as "very sufficient" (Table 7). As for their position, engineers, forest chiefs 
and managers of forest enterprises define themselves as "moderately sufficient" while deputy manager of forest enterprises, branch managers, managers and deputy managers of regional directorate mostly find themselves "very sufficient". Besides, less experienced employees and those with medium experience $(0-20$ years $)$ evaluate themselves to be "moderately sufficient" and those with high and quite high experience ( $\geq 21$ years) find themselves "very sufficient" (Table 7 ).

Table 7. Differences of participants' attitudes on administrative competence depending on region, department, position and experience

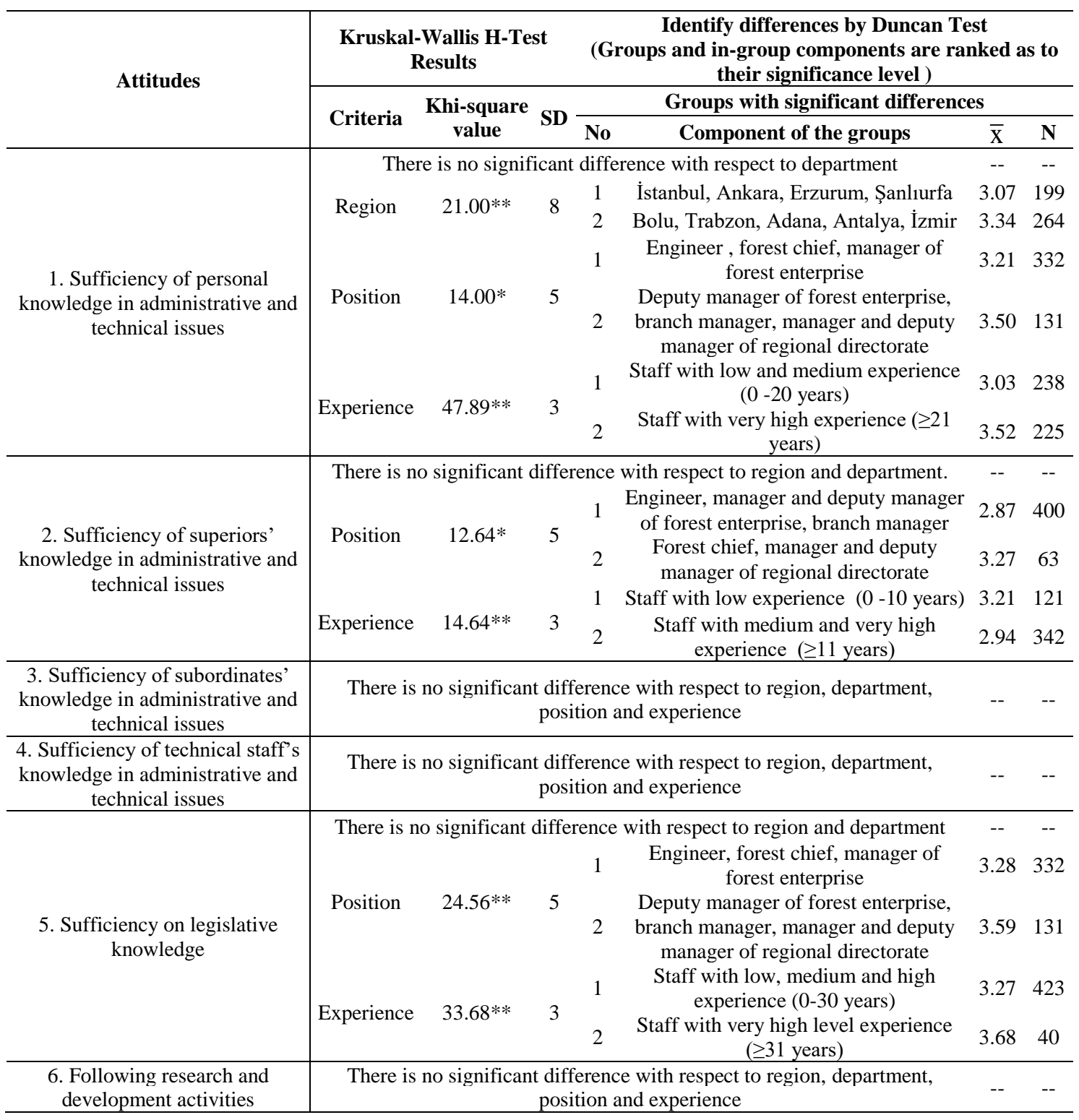

Sixty percent of the participant employees working in the forestry organization think that their superiors are "moderately sufficient" in forest resources management (Table 6). The attitudes of the participants do not indicate a significant difference depending on region and department with a reliability level of $95 \%$. However, when position and experience are considered a significant difference is observed in terms of 
reliability levels of $95 \%$ and $99 \%$ respectively. Engineers, managers and deputy managers of forest enterprises, and branch managers generally define their superiors "slightly sufficient" or "moderately sufficient". Forest chiefs, managers and deputy managers of regional forest directorates on the other hand, generally find their superiors "moderately sufficient" or "very sufficient". On the other hand, less experienced employees (0-10 years) in forest resources management generally find their superiors "moderately sufficient" or "very sufficient". Employees with medium, high and quite high experience ( $\geq 11$ years) think that their superiors are "moderately sufficient" or "slightly sufficient" (Table 7). It can be understood that the higher job experience levels that the employees have mean the less competence attitude on their superiors.

Sixty percent of the participants define their subordinates as "moderately sufficient" when their attitude is asked about forest resources management (Table 6). Region, department, position and experience difference do not have a significant effect on the attitudes of participants (Table 7).

When they are asked about the technical staff, $68 \%$ of the participants working in the forestry sector think that they are "moderately sufficient" in forest resources management (Table 6). Region, department, position and experience difference do not have a significant effect on the attitudes of participants (Table 7). Most of the participants find not only themselves but also their superiors - subordinates and technical staff "moderately sufficient" in forest resources management related issues.

The results showed that the staff defines themselves, their superiors and subornitaes and also the technical staff moderately sufficient in terms of aspects regarding forest resources management. This could be a prominent issue in terms of success of the organization. Determination of the related insufficiencies and their reason could have priority for the forestry sector in Turkey. Thus the key solutions could be designed for improving sustainability of forest resources. Also it was found out that the focus group should be engineers and forest chiefs who are at the lowest position and have much more task and workload. Besides both the managers, land managers and technical staff should be supported about their managerial ability related forest resources.

When the participants are asked as "How sufficient is your knowledge about the law, regulations and instructions etc. related to your position-department?" $52 \%$ of them define themselves as "moderately sufficient" on legislative knowledge. $34 \%$ state that they are "very sufficient" (Table 6). Region and department difference do not have a significant effect on the attitudes of participants. However, when their position and experience are considered, a significant difference can be observed with a reliability score of $99 \%$. While engineers, forest chiefs and managers of forest enterprises find themselves "moderately sufficient" and "very sufficient" on legislative, deputy managers of forest enterprises, branch managers, managers and deputy managers of regional forest directorates mostly state that they are "very sufficient" (Table 7). Particularly mid-level and senior managers such as branch manager, managers and deputy managers of regional forest directorates define themselves as more sufficient on legislative knowledge when compared with the rest of the employees is both ordinary and necessary. Employees with less, medium and high job experience (0-30 years) find themselves "moderately sufficient" and "very sufficient". Those with a quite high job experience ( $\geq 31$ years) define themselves as "very sufficient" on legislative knowledge (Table 7). It can be stated that the more experienced the employees become, the more sufficient they find themselves on legislative knowledge, which is a realistic situation. 
When they are asked as "Are you able to follow scientific studies and researches related to forestry?" $12 \%$ of the participants answer "Yes"; $26 \%$ "No" and $62 \%$ "Partially" (Table 6). It is observed that the participants (42\%) whose answer is "No" or "Partially", give the answer "I care about them but I am too busy" as an excuse for not being able to follow research and development activities and their outputs. The second most commonly (23\%) given excuse is "I don't follow because I don't find them applicable". As it can be concluded here, $65 \%(42+23)$ of the employee state that they are not able to follow research and development activities and their outputs because they do not have enough time or they do not follow them because of not believing the activities to be applicable. No significant difference depending on region, department, position and experience can be found related to the subject (Table 7).

It was found out that the staff evaluated their legal knowledge sufficiency at a high level. This is a favorable situation in terms of Turkish Forestry because there are lots of problems derived from application of legislations and the sufficiency of the technical staff about legislative issues makes the forestry organization stronger. However, the level of following research and development activities is low. The interaction between research and decision making and also implementation processes of forestry play critical role on organizational success. This potential should be developed by effective mechanisms to strengthen the managerial process of Turkish forestry.

\section{Results Related to Success Mentality}

The attitude of the managers, technical staff and the experts about administrative success, most important factors affecting success and success measurement systems were questioned at this part. Related institution representatives and the representatives from NGOs were also asked about their thoughts on administrative success in forestry. The results were given in the Table 8 . Besides, the question, whether participants' thoughts differ depending on region, department, position and experience was statistically analyzed and results were given in Table 9.

Seventy-for percent of the employees working in forestry sector, $76 \%$ of the experts, $63 \%$ of related institution representatives and $81 \%$ of NGO representatives replied the question "How do you identify administrative and organizational success in forestry?" as "achieving the goals through efficient use of resources". The answer by NGO representatives with the highest rate and accuracy indicates how conscious they are about the issue (Table 8). Region, department and position difference has no significant effect on the participants' thoughts. However, experience has an effect with a $99 \%$ reliability score. According to the Duncan's test score which was performed to find out which group is different, it is understood that the answer "achieving the goals through efficient use of resources" is more common among those with medium job experience (11-20 years) when compared with the answers of those with less, high and quite high job experience $(0-10$ years and $\geq 21$ years) (Table 9$)$.

Fifty-six percent of the employees and $73 \%$ of the experts identify "organizational and administrative factors such as organizational structure, administrative competence, number of the staff and their level of education as "the most important factors affecting success" (Table 8). No significant difference depending on region, position and experience can be found related to the subject (Table 9) but, a significant difference is found depending on departments with a reliability score of 95\%. According to Duncan's test results, employees working at the GDF and the GDCDE are more likely to identify 
"organizational and administrative factors" as "the most important factors affecting success" when compared with those working at the GDNCNP (Table 9).

The understanding of success of technical staff is toward achieving the goals through efficient use of resources. The common understanding about organizational success could contribute to coordination and cooperation in the forestry organization. Besides the participants evaluated organizational and administrative factors as the most important factor that affects the organizational success. The forest organization's structure is very complex and had changed many times in the historical period. This situation is seen as the source of many forestry-related problems. Also it is seen that it has effect on organizational success. Thus forming an effective organizational structure and administrative system seem to be a prominent aspect in terms of increasing the success of the organization.

Table 8. Attitudes of participants about administrative success in forestry

\begin{tabular}{|c|c|c|c|c|c|}
\hline \multirow[b]{2}{*}{ Attitudes } & \multirow[b]{2}{*}{ Scale } & \multicolumn{4}{|c|}{ Percentages of attitudes (\%) } \\
\hline & & Staff & Experts & $\begin{array}{l}\text { Representatives } \\
\text { of Related } \\
\text { Institutions } \\
\end{array}$ & $\begin{array}{l}\text { Representatives } \\
\text { of NGOs }\end{array}$ \\
\hline \multirow{7}{*}{$\begin{array}{l}\text { 1. Mentality of } \\
\text { administrative } \\
\text { and } \\
\text { organizational } \\
\text { success }\end{array}$} & a) Maximization of profit & 1 & 0 & 3 & 0 \\
\hline & $\begin{array}{l}\text { b) Maximization of goods and services } \\
\text { production }\end{array}$ & 2 & 3 & 3 & 3 \\
\hline & $\begin{array}{l}\text { c) Producing highest output from the } \\
\text { least input }\end{array}$ & 6 & 0 & 6 & 5 \\
\hline & $\begin{array}{l}\text { d) Achieving the goals through efficient } \\
\text { use of resources }\end{array}$ & 74 & 76 & 63 & 81 \\
\hline & $\begin{array}{l}\text { e) Producing the highest amount of } \\
\text { goods and services through the market } \\
\text { demand }\end{array}$ & 3 & 3 & 10 & 0 \\
\hline & $\begin{array}{l}\text { f) Fulfilling the need of society } \\
\text { regarding forest resources }\end{array}$ & 7 & 12 & 6 & 0 \\
\hline & g) Other & 7 & 6 & 9 & 11 \\
\hline \multirow{7}{*}{$\begin{array}{c}\text { 2. Most } \\
\text { important } \\
\text { factors affecting } \\
\text { success }\end{array}$} & $\begin{array}{l}\text { a) Physical factors (forest area, forest } \\
\text { stock, forest productivity, road density } \\
\text { etc.) }\end{array}$ & 4 & 3 & - & - \\
\hline & b) Economic and financial factors & 4 & 0 & - & - \\
\hline & c) Socio-economic factors & 18 & 15 & - & - \\
\hline & $\begin{array}{l}\text { d) Technical factors (technical } \\
\text { knowledge, number of machines etc.) }\end{array}$ & 7 & 0 & - & - \\
\hline & $\begin{array}{l}\text { e) Organizational and administrative } \\
\text { factors (organizational structure, } \\
\text { efficiency of managers, number and } \\
\text { training of staff etc.) }\end{array}$ & 56 & 73 & - & - \\
\hline & $\begin{array}{l}\text { f) Ecological and geographical factors } \\
\text { (location, climate, soil etc.) }\end{array}$ & 5 & 9 & - & - \\
\hline & g) Other & 6 & 0 & - & - \\
\hline \multirow{4}{*}{$\begin{array}{l}\text { 2. Attitudes on } \\
\text { success } \\
\text { measurement of } \\
\text { forestry } \\
\text { organization }\end{array}$} & $\begin{array}{l}\text { a) Assessment and Evaluation Unit that } \\
\text { will be established under Ministry or } \\
\text { General Directorate should measure the } \\
\text { organizational success by using some } \\
\text { objective criteria and depending on the } \\
\text { records of the organizations. }\end{array}$ & 49 & 67 & - & 54 \\
\hline & $\begin{array}{l}\text { b) Register managers should measure } \\
\text { the success by scoring the staff utilizing } \\
\text { criteria of standard forms. }\end{array}$ & 10 & 3 & - & 6 \\
\hline & $\begin{array}{l}\text { c) The success of the staff should be } \\
\text { measured by examination and } \\
\text { supervision system that will be managed } \\
\text { by an expert commission }\end{array}$ & 27 & 24 & - & 24 \\
\hline & d) Other & 14 & 6 & - & 16 \\
\hline
\end{tabular}


Forty-nine percent of the employees, $67 \%$ of the experts and $54 \%$ of the NGO representatives stated that organizational success should be considered when they were asked about "success measurement system for organizational structure success (performance)" (Table 8). No significant difference depending on region, department, position and experience can be found relating to this issue (Table 9).

Table 9. Difference of participants' attitudes on administrative success mentality depending on region, department, position and experience

\begin{tabular}{|c|c|c|c|c|c|c|c|}
\hline \multirow[t]{3}{*}{ Attitudes } & \multicolumn{3}{|c|}{$\begin{array}{l}\text { Kruskal-Wallis H-Test } \\
\text { Results }\end{array}$} & \multicolumn{4}{|c|}{$\begin{array}{c}\text { Identify differences by Duncan Test } \\
\text { (Groups and in-group components are ranked as to } \\
\text { their significance level ) }\end{array}$} \\
\hline & \multirow{2}{*}{ Criteria } & \multirow{2}{*}{$\begin{array}{l}\text { Khi-square } \\
\text { value }\end{array}$} & \multirow{2}{*}{ SD } & \multicolumn{4}{|c|}{ Groups with significant differences } \\
\hline & & & & No & Component of the groups & $\overline{\mathrm{X}}$ & $\mathbf{N}$ \\
\hline \multirow{3}{*}{$\begin{array}{l}\text { 1. Mentality of administrative } \\
\text { success in forestry }\end{array}$} & \multicolumn{5}{|c|}{$\begin{array}{l}\text { There is no significant difference with respect to region, department and } \\
\text { position. }\end{array}$} & -- & -- \\
\hline & \multirow{2}{*}{ Experience } & \multirow{2}{*}{$13.78 * *$} & \multirow[b]{2}{*}{3} & & $\begin{array}{l}\text { Staff with low, high and very high } \\
\text { experience }(0-10 \text { years and } \geq 21 \text { years })\end{array}$ & 51.36 & 346 \\
\hline & & & & & $\begin{array}{l}\text { Staff with medium experience }(11-20 \\
\text { years) }\end{array}$ & 64.04 & 117 \\
\hline \multirow{3}{*}{$\begin{array}{l}\text { 2. Most important factors } \\
\text { affecting success }\end{array}$} & \multicolumn{5}{|c|}{$\begin{array}{l}\text { There is no significant difference with respect to region, position and } \\
\text { experience. }\end{array}$} & -- & \\
\hline & \multirow{2}{*}{ Department } & \multirow{2}{*}{$6.54^{*}$} & \multirow{2}{*}{2} & & GDNCNP & 29.34 & 53 \\
\hline & & & & & GDF, GDCDE & 42.11 & 410 \\
\hline $\begin{array}{l}\text { 3. Attitudes on success } \\
\text { measurement system }\end{array}$ & \multicolumn{5}{|c|}{$\begin{array}{l}\text { There is no significant difference with respect to region, department, position } \\
\text { and experience. }\end{array}$} & -- & -- \\
\hline
\end{tabular}

Success measurement system is an important lack which has direct relations with the performance of staff and whole organization. While improving the system as the participants emphasized objectivity should be the essential principle. In other case the staff would develop a negative attitude towards the organizational justice.

\section{Results Related to Motivation and Reward}

Motivation has a great role on employees' willingness of fulfilling their tasks (Newman, 1972). Therefore, to increase the motivation of the employees shall increase the success. In this part of the study, the participants were asked their attitudes about the relationship between the success at work and designation, promotion and reward, what should be done to raise the motivation of the employees and accordingly to increase the success and how the performance measuring system should be within the structure of the organization. The answers by the participants were indicated in Table 10 and the question whether participants' thoughts differ depending on region, department, position and experience was statistically analyzed (Table 11).

Fifty-three percent of the employees answered "there is no relationship", 25\% answered "there is a slight positive relationship" and 14\% answered "there is an inverse relationship" the question "Is there a relationship between your success at work and designation, promotion, appreciation, premium and being rewarded?" The rate of those who find "very close relationship" is just $8 \%$. The answers of the experts for the same question are as follows: $49 \%$ "there is a slight positive relationship", $27 \%$ "there is no relationship" and 3\% "there is an inverse relationship" (Table 10). The difference of region and position has no significant effect on the participants' attitudes. However, it has been concluded that different departments (95\% reliability) and different job experiences (99\% reliability) have a significant effect on the issue. Employees working 
at the GDF generally think that there is no relationship between success and promotion or being rewarded whereas, the GDNCNP and the GDCDE employees generally think that there is a slight positive relationship. On the other hand, employees with high and quite high job experience ( $\geq 21$ years) find no relationship while less and mediumexperienced ones (0-20 years) generally think that there is a slight positive relationship (Table 11).

Table 10. Participants' attitudes about motivation and reward

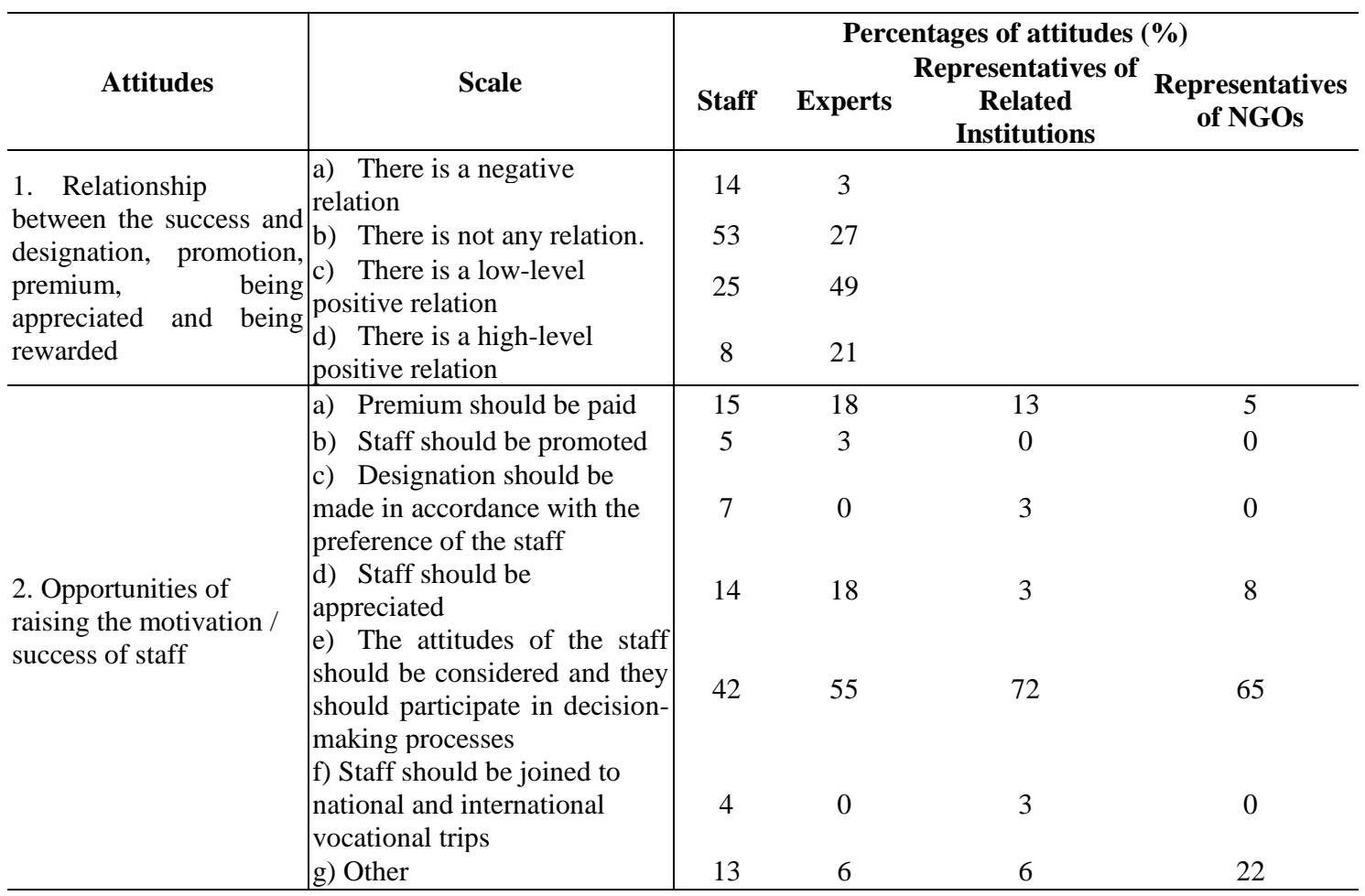

Forty-two percent of the employees, $55 \%$ of the experts, $72 \%$ of the relevant institution representatives and $65 \%$ of the NGO representatives answered the question "What should be done in order to raise the motivation/increase the success of the employees in forestry sector?" as "their attitudes should be considered and they should participate in decision-making processes" (Table 10). This approach was found to be dominant in all interest groups. No significant difference depending on region, department, position and experience can be found relating to this issue (Table 11).

This is one of the very critical results of the study. As the staff mentioned without contacting the success with designation, promotion, premium, being appreciated and being rewarded then the system could be evaluated as unjust by the staff. Also it's understood that the staff evaluated participation in decision making process and consideration of their attitudes as the main factor in rising the motivation and success. It should be considered in the context of national level policies on both decision making process and human resources management. Providing active participation of the staff would also support the participatory management mechanism which is also a lack for Turkish forestry. This result could also be a starting point of the new researches regarding administration and organizational behavior related studies for the country and the similar countries. 
Table 11. Difference of participants' attitudes about motivation and reward depending on region, department, position and experience

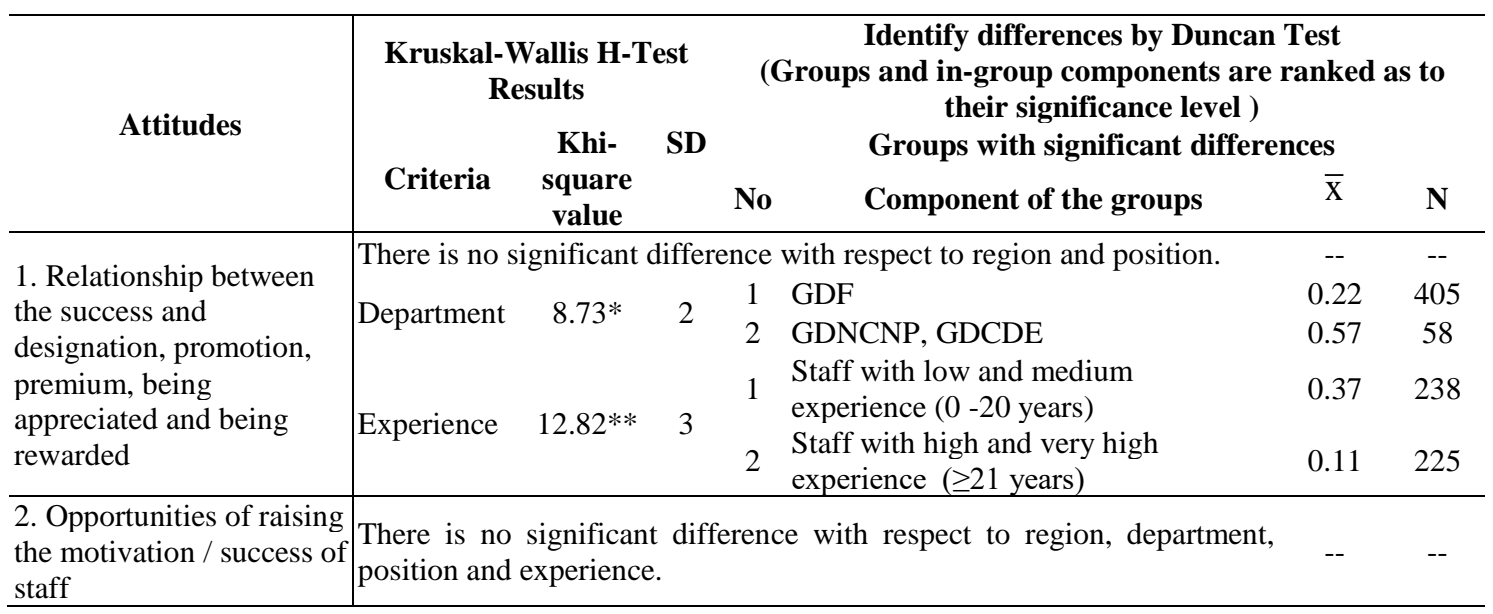

\section{Discussion}

The results of the study are important in terms of contribution of related national policy making process. Also the results contribute to analyze regional differences and gives opportunity to focus on local level decisions. Both the national and regional level findings can guide to the countries where the forests are publicly managed. Also the results represent the problems and trends of the forestry organizations that have complex organizational structure and managed centrally. Thus the study contributes to international literature and expresses decision makers in national and regional level managers of forestry organizations which have public institution characteristics.

In the study, the most important factors (education and self-development, administrative competence, success mentality, motivation and rewarding) affecting administrative and organizational success in the forest resource management of Turkey were analyzed and evaluated from the perspectives of staff, experts, representatives of related institutions and NGOs. According to the results, a great majority of the participants' think the undergraduate education is insufficient. However, it is seen that as the task duration increases the belief on the education provided by the faculties be sufficient increases as well. It is known that the rate of courses with socioeconomic content, accordingly socioeconomic aspect, is more important in forestry education and training in countries where modern forestry understanding is dominant (Geray, 1991, 1993; Lorincová et al., 2016). In some of the researches conducted in the country (İnal, 1968; Kalıpsız et al., 1969; Pamay et al., 1973; Çepel, 1984; Daşdemir, 1998), it has been determined that forest engineers mostly need courses with socioeconomic content whereas courses related to management and organization, public relations, decisionmaking methods and scientific research methods dominate provided education. The rate of the courses with socioeconomic content in the curriculum of forestry education in some of the universities in the USA, Australia and Sweden, differs from 23\% to $36 \%$ while this rate is only $14 \%-17 \%$ in Turkey (Elands et al., 2004). Therefore, the education system given in the forest faculties should be rearranged as compatible with contemporary forestry approach by considering the attitudes of all partners on the issue, particularly applied training and courses with socioeconomic content should be focused on. 
A large part of the participants' state prevocational and in-service training activities to be insufficient which suggests that prevocational and in-service training activities related to the profession should focus on self-improvement of administrators and technical staff besides being solution-oriented. It is observed that former studies had come a similar conclusion (Yurdakul, 2005; Şenyaz, 2008; Şafak, 2008).

Turkey forestry organization has encountered structural changes for several times due to political decisions that are not based on scientific foundations and that lack of participation principle and consequently the problems with administration, organization, planning, supervision etc. has increased and it has encountered problems in achieving organizational goals. Whereas it is necessary to increase the number of those who actually run the business within this context, it is seen that the number of senior managers had raised and the majority of the staff had gathered at the central organization.

Most of the employees, experts, relevant institution representatives and NGO representatives state that "the employees' attitudes should be considered and they should participate in decision-making processes" when the issue "What should be done in order to raise the motivation/increase the success of the employees in forestry sector?" is asked. No significant difference depending on region, department, position and experience can be found related this issue. In a study carried out among the technical staff employed at the İstanbul Regional Directorate of Forestry (Yurdakul Erol, 2017; Yurdakul Erol and Köse, 2017); the most satisfying factor is stated to be "the characteristic of the job to enable someone to do something for others". The second most satisfying component about the occupation is stated to be that "the job gives a chance to be a respectable person in the society". "To be able to find the opportunity to guide people" and "employment security" are also found to be other satisfying points of the occupation. As it can be understood from these results, regarding the employees' attitudes, participation in decision-making processes, the idea of being socially beneficial and the desire to be respected in the society should be used as means of motivation in forestry organization.

Organizational success (performance) is a multi-dimensional concept that indicates the level of achievement to organization goals according to contemporary management approach. Performance measurement systems that are not well designed prevent the organization from successfully adapting to the competitive environment. Because, performance measurement with incorrect methods leads to a reduction in the accuracy of the data that will support the application. In this context, it has been concluded that Measurement and Evaluation Center for Success to be established under Ministry or General Directorate should measure the organizational success by using some objective criteria and depending on the records of the organizations. This shows that the presence of a system based on entirely objective criteria without discrimination (attitudes, beliefs, race etc.) is preferred by the employees. Consequently, success measurement system which will be applied in this manner should form the basis for the institutional structure of forestry organization in Turkey and for promoting organizational success.

\section{Conclusion}

To achieve organizational success, determination of related problems by considering both internal and external stakeholders is an essential aspect for Turkish forestry. Also 
focusing on differences between the stakeholders and regions supports development of specific and solution-oriented decisions and implementations.

Especially education and training is one of the important factors that affect the organizational success as an instrument. Insufficiency about knowledge on socioeconomic issues was found out and then the observed prominent problems were parallel to this content. Besides, the interaction between scientific researches and forestry organization is the other key factor what could have direct affect on improvement of forestry organizations' success. The Turkish forestry experience also showed that the foremost factor that affects organizational success is related with organizational and administrative issues. The role of participatory management and objective performance measurement system was considered as the main components of success in Turkish forestry organization. These issues should be considered in forestry-related national level policy and strategy making processes immediately. Further, focusing on region and local level properties could increase the success of implementations of these policies and strategies.

Acknowledgements. This study was produced in the context of the research project entitled "Development of Alternative Organizational Models for Turkish Forestry" and numbered 10.5301/20142017 which was supported by the General Directorate of Forestry and directed by the Marmara Forestry Research Institute.

\section{REFERENCES}

[1] Akal, Z. (2005): Performance Measurement and Control in Business (Multiple Performance Indicators). - National Productivity Center, Publication No: 473, 368 p., Ankara (in Turkish).

[2] Aktan, Ü. (2013): Private forestry consulting firms and their effect on forest engineer employment. - Artvin Çoruh University, Graduate School of Natural and Applied Sciences, Department of Forest Engineering, Master Thesis 76 p., Artvin (in Turkish).

[3] Albuquerque da Silva, B., Guerra Gomes, N. M., Skowronski, L., Constantino de Oliveira, M. A., Brito da Costa, R. (2016): Multiple uses of forest resources in small and medium farms in the tropics: Economic and social contributions. - African Journal of Agriculture Research 11(41): 4162-4171.

[4] Baynes, J., Herbohn, J., Smith, C., Fisher, R., Bray, D. (2015): Key factors which influence the success of community forestry in developing countries. - Global Environmental Change 35: 226-238.

[5] Burns, S. L., Giessen, L. (2016): Dismantling comprehensive forest bureaucracies: Direct access, the World Bank, agriculture interests, and neoliberal administrative reform of forest policy in Argentina. - Society and Natural Resources 29(4): 493-508.

[6] Çepel, N. (1984): Relationship between forestry teaching and practice. - İstanbul University, Journal of Faculty of Forestry, Series B 34(1): 34-44. İstanbul (in Turkish).

[7] Daşdemir, İ. (1996): Determination of success levels in state forest enterprises (Example of North-East Anatolia and Eastern Black Sea Regions). - Ministry of Forestry, Eastern Anatolia Forestry Research Institute, Technical Bulletin No: 1, 161 p., Erzurum (in Turkish).

[8] Daşdemir, İ. (1998): Determination of Administrative and Organizational Dimensions of State Forest Districts. - Ministry of Forestry Eastern Anatolia Forestry Research Directorate, Technical Report Publication Number: 3, ISSN 1300-9486, 70 p., Erzurum (in Turkish). 
[9] Daşdemir, İ. (2016): Scientific Research Methods. - Nobel Academic Publishing and Consulting, Publication No: 1536, ISBN 978-605-320-442-8, 210 p, Ankara (in Turkish).

[10] Elands, B. H. M., O'Leary, T. N., Boerwinkel, H. W. J., Wiersum, K. F. (2004): Forests as mirror of rural conditions; local views on the role of forests across Europe. - Forest Policy and Economics 6: 469-482.

[11] Geray, A. U. (1991): Where are we at contemporary forestry education? - Chamber of Forest Engineers, Journal of Forest Engineering, February Count: 27-31. Ankara (in Turkish).

[12] Geray, A. U. (1993): Development and problems of forest resources management. I. Forestry Council. - Ministry of Forestry Publication No: 6, Series No: 13, Volume: 3: 137-149. Ankara (in Turkish).

[13] Gümüş, S., Beşir, S. (2012): The effect of motivation on organizational commitment and performance. - Hiperlink, ISBN 978944157513, 143 p., İstanbul (in Turkish).

[14] Gümüş, C. (2014): Effects of forestry policies from ottoman to present on forestry organization and current issues. - II. National Mediterranean Forest and Environment Symposium, 22-24 October, pp.477-489, Isparta (in Turkish).

[15] Hajjar, R., Oldekop, J. A. (2018): Research frontiers in community forest management. Current Opinion in Environmental Sustainability 32: 119-125.

[16] Hansmann, R., Kilchling, P., Seeland, K. (2016): The effects of regional forest owner organizations on forest management in the Swiss Canton of Lucerne. - Small-scale Forestry 15(2): 159-177.

[17] Hasanagas, N. D. (2014): Managing information in forest policy networks: Distinguishing the influential actors from the "postmen". - Forest Policy and Economics, http://dx.doi.org/10.1016/j.forpol.2014.09.007, Haugaard.

[18] Imamura, K. (1982): Human Resources in Japanese Forestry. - Unasylva No: 135.

[19] İnal, S. (1968): Forestry Higher Education in Turkey. - İstanbul University, Faculty of Forestry Publication No:1210/123, İstanbul (in Turkish).

[20] Kalıpsız, A., Gülen, İ., Tokmanoğlu, T. (1969): Report on education and education problems and solutions of forestry faculty of Istanbul University. - İstanbul (in Turkish).

[21] Kaplan, S. (1998): Are there problems in forestry management? - Forest and Hunting Journal 151: 22. Ankara (in Turkish).

[22] Kim, Y.-S., Bae, J. S., Fisher, L. A., Latifah, S., Afifi, M., Lee, S. M., Kim, I.-A. (2016): Indonesia's Forest Management Units: Effective intermediaries in REDD+ implementation? - Forest Policy and Economics 62: 69-77.

[23] Krott, M. (2005): Forest Policy Analysis. - Springer, ISNB 978-1-4020-3478-7 323 p. Netherlands.

[24] Lorincová, S., Hitka, M., Čambál, M., Szabó, P., Javorčiková, J. (2016): Motivational factors influencing senior managers in the forestry and wood-processing sector in Slovakia. - BioResources 11(4): 10339-10348.

[25] Lyons, K., Wlaters, P., Riddell, E. (2016): The role of faith-based organizations in Environmental governance: The case of Forestry in Solomon Islands. - Journal of Environmental Policy and Planning 18(3): 342-360.

[26] MacDicken, H. G., Sola, P., Hall, J. E., Sabogal, C., Tadoum, M., Wasseige, C. (2015): Global progress toward sustainable forest management. - Forest Ecology and Management 352: 47-56.

[27] Mendes, A. M. S. C. (2006): Implementation analysis of forest programs: some theoretical notes and an example. - Forest Policy and Economics 8(5): 512-528.

[28] MFWA (2016): Staffs records of the Ministry of Forestry and Water Affairs for 2016 year. - Ankara (in Turkish).

[29] Miteva, D. A., Loucks, C. J., Pattanayak, S. K. (2015): Social and environmental impacts of forest management certification in Indonesia. - PLoS ONE 10(7): 1-18.

[30] Newman, W. H. (1972): Management in Business and Public Administration. - Sevinç Printing Press, 529 p., Ankara. 
[31] Orhunbilge, A. N. (2000): Sampling Methods and Hypothesis Testing (Review and Expanded Second Edition). - Avcıol Printing \& Publishing, 420 p., İstanbul (in Turkish).

[32] Özdönmez, M., Akesen, A., Ekizoğlu, A. (1998): Forestry Management Knowledge. İstanbul University, Faculty of Forestry Publication No: 4157/457, Dilek Offset Printing, 357 pp., İstanbul (in Turkish).

[33] Pamay, B., Kalıpsız, A., Gülen, İ. (1973): Offers on organizing and working principle of forestry research in Turkey. - İstanbul University, Journal of Faculty of Forestry, Series B, Volume XXIII, Number 2, İstanbul (in Turkish).

[34] Pinstrup-Andersen, P., Pandya-Lorchi, R. (1998): Food security and sustainable use of natural resources: a 2020 vision. - Ecological Economics 26(1): 1-10.

[35] Sanchez Badini, O., Hajjar, R., Kozak, R. (2016): Critical success factors for small and medium forest enterprises: A review. - Forest Policy and Economics 94: 34-45.

[36] Schmithüsen, F. (1983): Human Resources Formation: The Weak Link in Forestry Development. - Unasylva No: 142.

[37] Szaro, R. C., Langor, D., Yapi, A. M. (2000): Sustainable forest management in developing world: science challenges and contributions. - Landscape and Urban Planning 47(3-4): 135-142.

[38] Şafak, İ. (2008): Profile of forest engineers in Aegean region. - Journal of Chamber of Forest Engineers 45(10-11-12): 22-26. Ankara (in Turkish).

[39] Toksoy, D., Bayramoğlu, M., Ayaz, H. (2011): A Research on the organizational and organizational problems of forest engineers in forestry. - Kahramanmaraş Sütçü İmam University, Journal of Natural Sciences, Special Issue: 180-184. Kahramanmaraş (in Turkish).

[40] Torres-Rojo, J. M., Moreno-Sánchez, R., Mendoza-Briseño, M. A. (2016): Sustainable forest management in Mexico. - Curr Forestry Rep 2: 93-105.

[41] Tumpach, C., Dwivedi, P., Izlar, R., Cook, C. (2018): Understanding perception of stakeholder groups about Forestry Best Management Practices in Georgia. - Journal of Environmental Management 213: 374-381.

[42] Wibowo, A., Giessen, L. (2015): Absolute and relative power gains among state agencies in forest related land use politics: The Ministry of Forestry and its competitors in the REDD+ Programme and the One Map Policy in Indonesia. - Land Use Policy 49: 131141.

[43] Wiley, C. (1997): What motivates employees according to over 40 years of motivation surveys? - International Journal of Manpower 18(3): 263-280.

[44] Yurdakul, S. (2005): Human resources management problems and results in forestry organization (discussing sample cases). - Istanbul University, Journal of Faculty of Forestry, Series A 55(1): 161-185. İstanbul (in Turkish).

[45] Yurdakul Erol, S. (2017): Various evaluations on human resources management in forestry in Turkey and the state of technical forestry staff. - Current Trends in Science and Landscape Management. ISBN 978-954-07-4338-7, St. Kliment Ohridski University Press, Sofia, 543-561.

[46] Yurdakul Erol, S., Köse, M. (2017): Job satisfaction of forestry technical staff: the case of İstanbul Regional Forestry Directorate. - Kastamonu University, Journal of Faculty of Economics and Administrative Sciences 18(1) ICEBSS 2017 Special Issue: 273-286. Kastamonu. 